\title{
Defoliation impacts on coppicing browse species in north- east Brazil
}

\author{
L.H. HARDESTY AND T.W. BOX
}

\section{Abatract}

A study was conducted to determine if manually cutting coppice growth from the stump once or twice in the first growing season, exposing the coppice to 2 periods of intensive goat browaing, or no defoliation of coppice caused mortality or compensatory growth in 4 tree species of the Brazilian cantinga. Sabia' Mimosa caesalpinia), and catingueira (Cuesalpinia pyrumidalis) suffered no mortality rezardless of treatment, but pau branco ( $A$ uxemma oncocalyx), and marmeleiro (Croton hemiargyreus) that were browsed or manually defoliated experienced significant mortality. In the year of treatment undefoliated and browsed trees of all species produced significantly more stem material than manually defoliated plants. Browsed catingueira produced more leaf material than undefoliated or manually defoliated plants. The year after treatment, undefoliated trees produced more leaf and stem than either browsed or manually defoliated trees. Normally pau branco and marmeleio are not browsed and both species suffered significant mortality after manual or browsing defoliation, suggesting they are not adapted to herbivory; whereas intact sabia' and catingueira are palatable and suffered no mortality following browsing or removal of coppice. Undefoliated trees produced more biomass than browsed or manually defoliated trees; thus, removal of coppice growth does not stimulate increased forage production. Browsed trees produced regrowth during the dry season when these species are normally leafiess. Manually defoliated trees did not, highlighting the fact that trees respond to browing differently than to manual defolintion. This study demonstrates that rezenerating cantinga stands can be manipulated through browsing or manual defoliation of coppice to achieve specific manazement objectives.

Key Words: sprouting, cantinga

Many woody species have adapted to defoliation by herbivory, whether it be feeding within the canopy by insects, monkeys, or birds, or browsing of young trees by ground dwellers. A species' adaptation to defoliation is determined by the season, severity, and cause of defoliation most frequently experienced. A problem arises when a tree is cut and begins to sprout from the stump (coppice). It has been observed that coppice growth is sometimes more palatable than the foliage of mature trees of the same species (Hallisey and Wood 1976, Leege and Hickey 1971, Lieberman and Lieberman 1984, Reynolds and Sampson 1943). Coppice is browsed by ground-dwelling herbivores as if it were a shrub or young tree, but the coppicing stump is neither and models of how seedlings or intact trees or shrubs respond to browsing are not satisfactory when dealing with coppice growth. For example, the coppicing stump has the fully developed root system of a mature tree, but

\footnotetext{
At the time of this research, authors were research associate, Department of Ranse Science; and dean, College of Natural Resources, Utah State University, Logan 84322. Hardesty is currently assistant professor, Department of Forestry and Range Management, Washington State University, Pullman 99164.

This research was carried out as a part of the U.S. Agency for International Development Title XII Small Ruminants Collaborative Research Support Program under Grant No. AID/DSAN/XII-C-0049, in collaboration with the Empresa Brasileira de Pesquisa Agropequaria, and Empresa de Pesquisa Agropequaria do Ceará. Manuscript preparation was supported by the Department of Forestry and Range Management, Washington State University. The authors wish to thank Dan Hardesty and their Brazilian collaborators for logistical support and John Teberg and Dr. Roger Chapman for assistance with data analysis. Parts of this paper appear in the senior author's Ph.D. disactation at Utah State University.

This paper was approved by the director, Washington State University Agricultural Research Center, as Scientific Paper 7556, Project 0671.

Manuscript accepted 29 June 1987.
}

lacks the root reserves characteristic of shrubs (Garrison 1972). Because trees store carbohydrates in twigs and branches, the coppicing plant loses substantial reserves as well as photosynthetic capacity when browsed. Coppicing involves growth characteristics different from both the seedling and the intact mature tree. This is often referred to as juvenility (Schaffalitzky de Muckadell 1962, Zimmerman and Brown 1971). Young trees and shrubs of some species have mechanisms for coping with herbivory which are not found in mature trees (Bryant et al. 1985). However, there is no satisfactory paradigm to explain how the coppicing plant deals with herbivory.

Given that coppicing has caused the failure of many brush control programs and that coppicing is an age-old forest management technique, there is surprisingly little information available about the factors influencing coppicing or mechanisms involved. For example, several brush control techniques used in northeast Brazil are based on the hypothesis that defoliation of the sprouting stump reduces subsequent sprout production. However, this hypothesis had not been tested experimentally. A better understanding of coppicing might increase land management options in this region.

Crop and livestock production are closely integrated in northeast Brazil where slash and burn agriculture is a centuries-old tradition. The native woodlands (caatingas) are cut and burned, farmed or grazed for a few years, then abandoned to regenerate before the cycle is repeated. Sheep and goats are the primary livestock of the small scale producer. These livestock graze intact and regenerating caatinga stands where fallen leaves of several tree species are a key forage source during the 6-9 month dry season (Pfister and Malechek 1986). Caatinga clearing is necessary for wood harvest, crop, and pasture production. But once the caatinga is cleared, there is less dry season forage (Kirmse 1984), and animal production suffers (Huss 1976).

Coppicing must be controlled to maintain caatinga clearings. Undesirable coppice is reduced by piling and burning slash on the stumps of least desirable trees, excavating stumps, slashing regrowth, or permitting sheep and goat browsing. These methods are either labor intensive or non-selective, and as practiced, are not effective over large areas. When coppicing is desirable, as in the case of sabia' (Mimosa caesalpinifolia), a source of excellent fence posts, no special management is applied.

The traditional land management scheme could be improved by: (1) maintaining or increasing dry season forage production while maintaining production of herbaceous forages and wood, (2) controlling regrowth of undesirable woody species, and (3) maintaining or enhancing environmental stability. Coppice management is one possibilty, but little is known of the effect of manipulation on coppice growth.

This study quantifies the response of several caatinga species to manual defoliation and browsing of coppice growth. The objectives were to determine if defoliation' of coppice growth causes either stump morality or compensatory growth, to compare the effects of manual defoliation and heavy browsing on coppice production, and to compare the effect of manual defoliation and

'Defoliation is used to denote removal of coppice growth, either manually, or by browsing, as compared to the control treatment of no removal of coppice. 
browsing on coppice growth of 4 different, but closely associated species.

\section{Study Area}

The study was conducted at the Brazilian National Goat Research Center, near Sobral, Ceará ( $3 \mathrm{~S}, 40 \mathrm{~W}$ ), at $63 \mathrm{~m}$ elevation. The average annual rainfall is $759 \mathrm{~mm}$, and extremely variable. During the study (1982-1984) rainfall was 650,447 , and $986 \mathrm{~mm}$, respectively. Rainfall is normally concentrated in the first 4 months of the year, followed by a long dry season which often extends into prolonged drought. Potential evaporation ranges from 1,000-1,500 $\mathrm{mm} / \mathrm{yr}$ (Camargo 1965, Eiten and Goodland 1979). Topography is gently rolling and the soils are shallow $(<.5 \mathrm{~m})$, moderately to well drained lithosols, podzols, and non-calcic brown soils (Ramos 1981, Queiroz 1985).

The vegetation is mature caatinga dominated by pau branco (Auxemma oncocalyx), catingueira (Caesalpinia pyramidalis), and sabia. The stand is about 50 years old. The average density of stems greater than $1 \mathrm{~cm}$ diameter is $2,500 / \mathrm{ha}$, with a 6 to $10-\mathrm{m}$ high canopy almost uniformly closed. The sparse understory consists of seedlings of a variety of tree species, a few shrubs, vines, and annual forbs.

Four tree species typical of the region were studied. Catingueira and sabia' are valuable forage species. Sabia' wood is excellent for fenceposts, or fuelwood, but catingueira has only marginal wood value. Marmeliero (Croton hemiargyreus) is a woody invader of little value for forage or wood. Pau branco produces timber and fuelwood, but is rarely browsed by sheep or goats.

\section{Methods}

Each treatment was replicated 3 times within a randomized block design. Plots included 6 trees of each species studied. The trees were within the modal diameter class for the stand and had no visible sign of injury or disease. Plots were clearcut using hand tools in the traditional manner during the dry season in November 1982. Usable wood was removed and the slash hauled away from the stumps. Stumps were cut at $30 \mathrm{~cm}$ above-ground and protected from grazing. All stumps coppiced at the beginning of the 1983 rainy season (January). In March 1983, defoliation treatments were applied that consisted of:

no defoliation of coppice growth (U)

one manual defoliation (1 M)

two manual defoliations ( $2 \mathrm{M}$ )

two periods of heavy goat browsing (2 B)

Manual defoliation consisted of cutting all sprouts from the stump at the point of origin. The number of sprouts was recorded, the material removed, sorted into leaf and stem fractions, oven dried at $65^{\circ} \mathrm{C}$ for $48 \mathrm{hr}$, and weighed. Plots to be browsed were fenced and supplied with water. Double sampling using dimensional analysis was used to estimate coppice biomass (Hardesty 1987).The height, longest diameter and a perpendicular diameter of each coppice clump was measured. Two randomly selected trees of each species in each replication were harvested. Coppice material was then cut from these stumps, separated into leaves and stems, oven dried, and weighed. The dimensions of the remaining coppice clumps were used to estimate production with regressions developed from the harvested clumps.

Browsing treatments were accomplished by releasing 10 young castrated male goats into each plot. Treatments were terminated when very little herbage remained in the plots. The plots averaged 0.18 ha, resulting in an effective stocking density of 55.6 goats/ ha. Stumps were examined after browsing for remaining sprouts and the occurrance of bark removal.

Defoliated stumps produced new coppice within days of the initial treatment. In May, treatments were repeated on the browsed (2 B) and manually defoliated ( $2 \mathrm{M})$ plots. Treatment procedures were unchanged except that 13 goats were used for 16 days. Both browsing treatments were applied before coppice growth had grown out of reach of the goats.

At the end of the growing season (August 1983), total production was determined for each stump using the double sampling procedure described earlier. The amount of material removed for each stump during the treatments was added to season-end biomass to determine total production for the season.

Coppice grew undisturbed through the 1984 growing season. At the end of the season, coppice growth was harvested from all surviving stumps using the same procedure as in 1983. Data were not available from the single manual defoliation group in 1984.

Analysis of variance was performed on stem weight, leaf weight, combined stem and leaf weight, and leaf/stem biomass ratio using the SAS statistical package (Statistical Analysis Systems 1986). Separate analyses were done for 1983 and 1984 total production, and the sum of 1983 and 1984 production. Homoscedasticity was tested using Cochran's test (Guenther 1964). Fisher's protected LSD was used to compare means at $\alpha=.05$. Mortality at the end of 2 years was analyzed as a comparison of proportions using $\mathrm{Chi}$ squared as described by Fleiss (1981).

\section{Results}

\section{Mortality}

Sabia' and catingueira suffered no mortality regardless of treatment (Table 1). Marmeleio and pau branco experienced significant $(P<.05)$ mortality, and defoliation treatments resulted in more

Table 1. Mortality aswociated with species and defollation treatments of 4 caatinga species of northeast Braxl.

\begin{tabular}{lccc}
\hline \hline Species & $\begin{array}{c}\text { Defoliation* } \\
\text { treatment }\end{array}$ & $\begin{array}{c}\text { Total } \\
\text { trees }\end{array}$ & $\begin{array}{c}\text { Trees } \\
\text { killed }\end{array}$ \\
\hline catingueira & $2 \mathrm{M}$ & 31 & 0 \\
& $2 \mathrm{~B}$ & 18 & 0 \\
sabia' & $\mathrm{U}$ & 20 & 0 \\
& $2 \mathrm{M}$ & 29 & 0 \\
marmeliero & $2 \mathrm{~B}$ & 18 & 0 \\
& $\mathrm{U}$ & 30 & 0 \\
pau branco & $2 \mathrm{M}$ & 10 & 7 \\
& $2 \mathrm{~B}$ & 6 & 1 \\
& $\mathrm{U}$ & 11 & 1 \\
& $2 \mathrm{M}$ & 30 & 3 \\
& $2 \mathrm{~B}$ & 18 & 5 \\
\hline
\end{tabular}

- $2 \mathrm{M}=$ manually defolinted twice

$2 \mathrm{~B}=$ browsed during 2 periods

$\mathrm{U}=$ no defoliation of coppice growth

mortality than the undefoliated controls (Table 2). Manually defoliated marmeleiro suffered more mortality than browsed marmeleio. Manually defoliated and browsed pau branco experienced equal mortality $(P<.05)$. Too few marmeleio survived to provide reliable data on biomass production.

Table 2. Comparison of proportions of dead trees associated with species and defollation treatments in northeast Braxl.

\begin{tabular}{lcc}
\hline \hline Comparison & $X^{2} .05$ & $X^{2}$ diff. \\
\hline all catingueira and sabia' vs all marmeliero and & 3.84 & 27.10 \\
$\quad$ pau branco & & \\
all marmeliero vs all pau branco & 3.84 & 7.87 \\
defoliated vs undefoliate pau branco & 3.84 & 5.57 \\
2 manual vs 2 browsed pau branco & 3.84 & 2.56 \\
defoliated* vs undefoliated marmeliero & 3.84 & 4.90 \\
2 manual vs 2 browsed marmelicro & 3.84 & 4.26 \\
\hline
\end{tabular}

- Manual defoliation and browsing treatments combined. 
Table 3. Mean 1983 biomass production ( $\mathrm{d} \mathrm{dry}$ weight) of individual trees of 3 cantinga species in northeast Braxil.

\begin{tabular}{|c|c|c|c|c|}
\hline $\begin{array}{l}\text { Defoliation* } \\
\text { Treatment }\end{array}$ & $\begin{array}{l}\text { Stem } \\
\text { weight } \\
\text { (n) }\end{array}$ & $\begin{array}{c}\text { Leaf } \\
\text { weight } \\
\text { (n) }\end{array}$ & $\begin{array}{l}\text { Total } \\
\text { weight } \\
\text { (n) }\end{array}$ & $\begin{array}{l}\text { Leaf/Stem } \\
\text { biomass ratio } \\
\text { (n) }\end{array}$ \\
\hline & \multicolumn{4}{|c|}{ Catingueira } \\
\hline $\mathrm{U}$ & $\begin{array}{c}391 \mathrm{a} \\
(30)\end{array}$ & $\begin{array}{c}341 \mathrm{a} \\
(30)\end{array}$ & $\begin{array}{c}731 \mathrm{a} \\
(30)\end{array}$ & $\begin{array}{l}.91 \mathrm{a} \\
(30)\end{array}$ \\
\hline $2 B$ & $\begin{array}{c}358 \mathrm{a} \\
(14)\end{array}$ & $\begin{array}{c}393 \mathrm{a} \\
(14)\end{array}$ & $\begin{array}{l}751 \mathrm{a} \\
(14)\end{array}$ & $\begin{array}{l}1.43 \mathrm{a} \\
(14)\end{array}$ \\
\hline $1 \mathrm{M}$ & $\begin{array}{c}191 \mathrm{~b} \\
(17)\end{array}$ & $\begin{array}{c}250 \mathrm{a} \\
(17)\end{array}$ & $\begin{array}{c}442 \mathrm{~b} \\
(17)\end{array}$ & $\begin{array}{c}1.28 \mathrm{a} \\
(17)\end{array}$ \\
\hline \multirow[t]{2}{*}{$2 \mathbf{M}$} & $\begin{array}{c}129 \mathrm{~b} \\
(32)\end{array}$ & $\begin{array}{c}207 a \\
(32)\end{array}$ & $\begin{array}{c}336 \mathrm{~b} \\
(32)\end{array}$ & $\begin{array}{c}1.69 \mathrm{a} \\
(32)\end{array}$ \\
\hline & \multicolumn{4}{|c|}{ Pau Branco } \\
\hline $\mathrm{U}$ & $\begin{array}{c}735 \mathrm{a} \\
(30)\end{array}$ & $\begin{array}{c}442 \mathrm{a} \\
(30)\end{array}$ & $\begin{array}{c}1176 a \\
(30)\end{array}$ & $\begin{array}{l}.67 \mathrm{~b} \\
(30)\end{array}$ \\
\hline 2B & $\begin{array}{c}442 b \\
(17)\end{array}$ & $\begin{array}{c}264 \mathrm{~b} \\
(13)\end{array}$ & $\begin{array}{c}702 \mathrm{~b} \\
\text { (13) }\end{array}$ & $\begin{array}{l}.64 \mathrm{~b} \\
\text { (13) }\end{array}$ \\
\hline $1 \mathrm{M}$ & $\begin{array}{l}161 \mathrm{c} \\
(18)\end{array}$ & $\begin{array}{l}193 \mathrm{c} \\
(18)\end{array}$ & $\begin{array}{c}354 \mathrm{c} \\
(18)\end{array}$ & $\begin{array}{c}1.25 \mathrm{a} \\
(18)\end{array}$ \\
\hline \multirow[t]{2}{*}{$2 \mathbf{M}$} & $\begin{array}{l}143 c \\
(30)\end{array}$ & $\begin{array}{l}181 \mathrm{c} \\
(30)\end{array}$ & $\begin{array}{l}324 \mathrm{c} \\
(30)\end{array}$ & $\begin{array}{c}1.30 \mathrm{a} \\
(30)\end{array}$ \\
\hline & \multicolumn{4}{|c|}{ Sabia' } \\
\hline $\mathbf{U}$ & $\begin{array}{c}297 \mathrm{a} \\
(31)\end{array}$ & $\begin{array}{c}212 \mathrm{a} \\
(31)\end{array}$ & $\begin{array}{c}508 \text { a } \\
(31)\end{array}$ & $\begin{array}{l}.74 \mathrm{c} \\
(31)\end{array}$ \\
\hline 2B & $\begin{array}{c}228 \mathrm{a} \\
(16)\end{array}$ & $\begin{array}{l}167 \mathrm{a} \\
(15)\end{array}$ & $\begin{array}{l}397 \mathrm{ab} \\
\text { (14) }\end{array}$ & $\begin{array}{l}.79 \mathrm{c} \\
\text { (14) }\end{array}$ \\
\hline IM & $\begin{array}{c}132 \mathrm{~b} \\
(14)\end{array}$ & $\begin{array}{c}151 \mathrm{a} \\
(14)\end{array}$ & $\begin{array}{c}283 \mathrm{~b} \\
(14)\end{array}$ & $\begin{array}{c}1.17 \mathrm{~b} \\
(14)\end{array}$ \\
\hline $2 \mathbf{M}$ & $\begin{array}{c}121 b \\
(24)\end{array}$ & $\begin{array}{c}164 a \\
(25)\end{array}$ & $\begin{array}{c}289 \mathrm{~b} \\
(21)\end{array}$ & $\begin{array}{c}1.42 \mathrm{a} \\
(24)\end{array}$ \\
\hline
\end{tabular}

For each species, values within a column followed by the same letter are not significantly different $(P<.05)$ by the LSD test (Steel and Torrie, 1980).

* IM = manually defoliated once

$2 M=$ manually defoliated twice

$2 \mathrm{~B}=$ browsed during 2 periods

$\mathrm{U}=$ no defoliation of coppice growth

tCalculated as mean of sums rather than sum of means.

\section{Total Biomass Production}

All species had similar patterns of stem production. Trees manually defoliated once or twice produced comparable $(P<.05)$ amounts of stem biomass (Table 3 ). Undefoliated trees, and those which were browsed by goats produced significantly $(P<.05)$ more stem biomass than the manually defoliated trees. Only in the case of pau branco did undefoliated plants produce significantly more stem biomass than the browsed plants.

Leaf production by catingueira and sabia' was similar under all treatments $(P<.05)$. Production by undefoliated pau branco was significantly greater than that of defoliated plants, and browsed plants produced significantly more leaf than manually defoliated plants. There was no significant difference in leaf production between pau branco manually defoliated once or twice. Inevitably some regrowth occurred during the browsing treatments. However, the goats' avid feeding on new growth minimized its contribution to total production.

Analysis of total weight (stem plus leaf) did not differ $(\boldsymbol{P}<.05)$ from stem weight alone except in the case of browsed sabiá, which did not produce significantly more than the manually defoliated trees nor less than the undefoliated ones. The leaf/stem biomass ratio of browsed and control plants did not differ $(P<.05)$ for pau branco and sabia', but these ratios were significantly less than the ratio for manually defoliated plants. Only sabia' exhibited any difference between the leaf/stem ratios of the 2 manually treated groups, with the trees defoliated twice having a higher ratio.

\section{Biomass Production}

At the end of the 1984 growing season, nondefoliated trees of all species had more $(P<.05)$ stem material than the browsed or twice
Table 4. Mean 1984 biomass production (s dry weight) of individual trees of 3 cantinge species in northeat Brazil.

\begin{tabular}{|c|c|c|c|c|}
\hline $\begin{array}{l}\text { Defoliation * } \\
\text { Treatment }\end{array}$ & $\begin{array}{c}\text { Stem } \\
\text { weight } \\
\text { (n) }\end{array}$ & $\begin{array}{l}\text { Leaf } \\
\text { weight } \\
\text { (n) }\end{array}$ & $\begin{array}{l}\text { Total } \dagger \\
\text { weight } \\
\text { (n) }\end{array}$ & $\begin{array}{l}\text { Leaf/Stem } \\
\text { biomass ratio } \\
\text { (n) }\end{array}$ \\
\hline & \multicolumn{4}{|c|}{ Catingueira } \\
\hline $\mathbf{U}$ & $\begin{array}{c}2851 \text { a } \\
(20)\end{array}$ & $\begin{array}{c}568 \mathrm{a} \\
(20)\end{array}$ & $\begin{array}{c}3419 \mathrm{a} \\
(20)\end{array}$ & $\begin{array}{l}.23 \mathrm{a} \\
(20)\end{array}$ \\
\hline 2B & $\begin{array}{c}1414 \mathrm{~b} \\
(13)\end{array}$ & $\begin{array}{c}431 \mathrm{a} \\
(13)\end{array}$ & $\begin{array}{c}1845 \mathrm{~b} \\
(13)\end{array}$ & $\begin{array}{l}.48 \mathrm{a} \\
(13)\end{array}$ \\
\hline $2 \mathrm{M}$ & $\begin{array}{c}1102 \mathrm{~b} \\
(21)\end{array}$ & $\begin{array}{l}480 \mathrm{a} \\
(21)\end{array}$ & $\begin{array}{c}1582 \mathrm{~b} \\
(21)\end{array}$ & $\begin{array}{l}.45 \mathrm{a} \\
(21)\end{array}$ \\
\hline
\end{tabular}

\begin{tabular}{lcccl} 
& \multicolumn{4}{c}{ Pau Branco } \\
& $3385 \mathrm{a}$ & $957 \mathrm{a}$ & $4342 \mathrm{a}$ & $.26 \mathrm{a}$ \\
2B & $(20)$ & $(20)$ & $(20)$ & $(20)$ \\
& $1408 \mathrm{~b}$ & $478 \mathrm{~b}$ & $1886 \mathrm{~b}$ & $.36 \mathrm{a}$ \\
2M & $(9)$ & $(9)$ & $(9)$ & $(9)$ \\
& $1067 \mathrm{~b}$ & $461 \mathrm{~b}$ & $1528 \mathrm{~b}$ & $.74 \mathrm{a}$ \\
& $(19)$ & $(19)$ & $(19)$ & $(19)$ \\
$\mathrm{U}$ & \multicolumn{4}{c}{ Sabia' } \\
2B & $3454 \mathrm{a}$ & $561 \mathrm{a}$ & $4015 \mathrm{a}$ & $.19 \mathrm{~b}$ \\
2M & $(22)$ & $(22)$ & $(22)$ & $(22)$ \\
& $1692 \mathrm{~b}$ & $440 \mathrm{ab}$ & $2131 \mathrm{~b}$ & $.29 \mathrm{a}$ \\
& $1130 \mathrm{~b}$ & $222 \mathrm{~b}$ & $1350 \mathrm{~b}$ & $.27 \mathrm{a}$ \\
& $(18)$ & $(18)$ & $(18)$ & $(18)$ \\
\hline
\end{tabular}

For each species, values within a column followed by the same letter are not significantly different $(P<.05)$ by the LSD test (Steel and Torrie, 1980).

$\because 2 M=$ manually defoliated twice.

$2 \mathrm{~B}=$ browsed during 2 periods

$\mathrm{U}=$ no defoliation of coppice growth

$\dagger$ Calculated as mean of sums rather than sum of means.

defoliated trees (Table 4). There were no significant differences in stem production between browsed trees and those which were manually defoliated twice.

Catingueira leaf production was less under defoliation treatments, but the decline was not significant $(P<.05)$. Pau branco controls had significantly more leaf material than treated trees. Manually defoliated sabia' produced significantly less leaf than the controls. Leaf production by browsed sabiá was intermediate between the control and manually defoliated groups.

Total biomass production is dominated by the stem fraction and follows the same pattern as stem biomass production. The leaf/stem biomass ratios for 1984 were considerably lower than for 1983. In 1984 there was a significant $(P<.05)$ difference between treatment groups of pau branco and sabia': browsed and defoliated trees had lower leaf/stem ratios than manually defoliated trees. In 1984 , only undefoliated sabia' had a significantly lower leaf/stem ratio compared to the other treatments.

\section{3-1984 Comblned Production}

The data in Table 4 could be misleading because the control trees have accumulated 2 years of stem growth to be compared to a single year's growth by the defoliated trees. When production for the 2 years is combined (Table 5) to determine cumulative production, the effect of defoliation is less pronounced. Undefoliated pau branco and catingueira produced more $(P<.05)$ stem material than either manually defoliated or browsed trees. There was no significant difference in stem production between browsed and manually defoliated stumps. Undefoliated sabia' produced more $(P<.05)$ stem material than manually defoliated sabia', and production by browsed trees was intermediate between the two.

Sabia' leaf production did not vary significantly with treatment. Undefoliated pau branco produced more $(P<.05)$ leaf than defoliated pau branco. There was no significant difference between undefoliated and browsed catingueira. Manually defoliated catingueira produced less $(P<.05)$ leaf than the undefoliated or browsed trees.

Total production followed the same pattern as stem production. 
Table 5. 1983-1984 Combined biomass production (s dry weight) of 3 cantinga species in northeast Braxil.

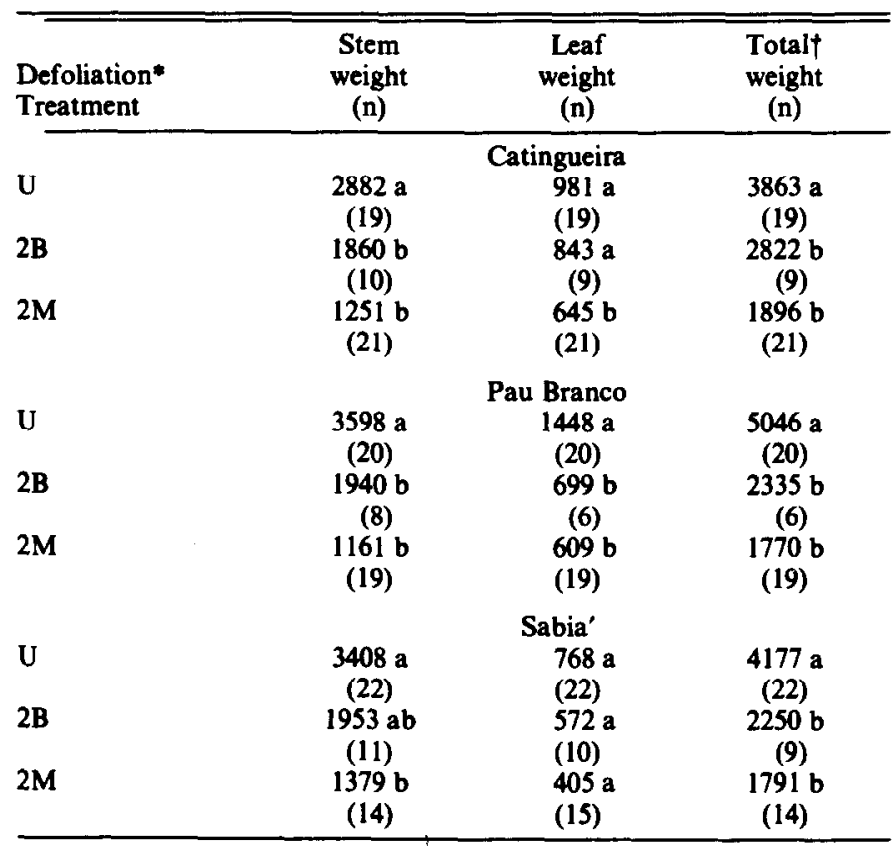

For each species values within a column followed by the same letter are not significantly different $(R<.05)$ by the LSD test (Steel and Torrie, 1980).

$* 2 \mathrm{M}=$ manually defoliated twice

$2 \mathrm{~B}=$ browsed during 2 periods

$\mathrm{U}=$ no defoliation of coppice growth

$\uparrow$ Calculated as means of sum rather than sum of means.

In all cases total production was significantly $(P<.05)$ greater for undefoliated plants, with a nonsignificant tendency for browsed plants to produce more than manually defoliated plants.

\section{Discussion}

Only those species which are not normally browsed (marmeliero, pau branco) experienced significant mortality. The more palatable species (catingueira and sabia) have apparently adapted to browsing and can survive cutting followed by 2 severe defoliations within a year. All 4 species experience regular insect defoliation. Caterpillars often strip the leaves from entire trees early in the rainy season and grasshoppers consume large amounts of leaf material later in the year, but even severe insect outbreaks are not reported to cause tree mortality in this area. A major difference between insect feeding and livestock browsing is that insects rarely attack stems and twigs, while goat browsing often removes stem material and associated buds. Carbohydrates contained in the stems that are lost during browsing are available for regrowth following insect defoliation. This might account for goat browsing causing greater mortality than insect feeding.

The idea that defoliation might result in compensatory growth exceeding that of the undefoliated group was not supported by these results. In 1983, production by browsed catingueira and sabia' was equivalent to production by the undefoliated stumps, but manually defoliated trees produced less stem material. Leaf production was less affected by defoliation than stem production although this proved to be short-lived, probably due to the tendency to replace leaf material before stem. By 1984, stem and leaf production by the undefoliated stumps exceeded that of all browsed and manually defoliated stumps. Apparently, severe defoliation cannot be used to stimulate increased forage production.

Browsing and manual defoliation occur very differently, the first incrementally over time, and the latter instantaneously and completely. Browsing late in the season tends to leave short stubs of stem attached to the stump. These stubs include buds that can sprout rapidly. In this experiment, manual defoliation removed the sprouts flush with the stump, and although regrowth tended to be concentrated in the vicinity of the scar, it is slower to appear than on the browsed stumps. In contrast, browsing causes more damage to the bark which, especially in the case of catingueira, is often consumed. Total biomass production over the 2-year period was not significantly affected by those differences although there was a consistent trend toward reduced production by the manually defoliated stumps.

The most striking difference between the browsed and manually defoliated stumps is that in 1983, the browsed stumps leafed out again during the dry season. None of the manually defoliated stumps produced regrowth during the dry season. This has implications which may constitute the most important difference between manual defoliation and browsing. Because all of the stumps were harvested at the end of the 1984 growing season, we do not know if this behavior persists.

Not all caatinga tree species respond similarly to defoliation of the coppicing stump. As noted earlier, sabia' and catingueira are more tolerant of repeated defoliation than are marmeleiro and pau branco. Furthermore, differences exist between the response of these two more sensitive species. Differences between species can be exploited when managing the regenerating caatinga stand. The density of pau branco and marmeleiro in the regenerating stand can be controlled through defoliation of coppicing stumps, reducing competition with the more desirable forage species. Trees producing usable wood (sabia' and some pau branco) could be cut with high stumps to put regrowth out of reach of browsers. Leaves could still be consumed when abscised, without risk of meristems being damaged by browsing.

Coppicing affects palatability as well as accessibility of forage. Green coppice of catingueira was consumed although mature plants of this species are not normally browsed when green. Coppice growth of marmeliero and pau branco was readily browsed even though mature plants of these species are rarely browsed. If access to marmeleio and pau branco coppice is allowed while it is palatable, the total forage supply will be increased through inclusion of previously shunned species in the diet. It is not clear if dried leaves of marmeleiro and pau branco coppice are more palatable than dry leaves of intact trees. Those species which produce palatable dry leaves (catingueira and sabia) could be cut with high stumps, or allowed to grow out of reach in order to defer their production for dry season use.

This study supports the idea that regenerating caatinga stands can be manipulated to achieve specific management objectives for different woody species and different woodland products. Similar treatments may have promise in the semiarid woodlands of Africa, central America, Asia and Australia, as well as the southeastern U.S.

\section{Literature Cited}

Bryant, J.P., P. Relehardt, T. Chusen, and F.S. Chapin, III. 1985. Adaptation to resource availability as a determinant of chemical defense strategies in woody plants. Rec. Adv. Phytochem. 19:219-237.

Camargo, M. 1965. An outline of the Brazilian soils. Proc. 9th Inter. Grassl. Cong. 9:9-16.

Eiten, G., and R. Goodland. 1979. Ecology and management of semi-arid ecosystems in Brazil. P. 277-301. In: B.H. Walker (ed), Management of semi-arid ecosystems. Elsevier Scientific Publishing Co., Amsterdam.

Fleiss, J.L. 1981. Statistical methods for rates and proportions. John Wiley \& Sons, New York.

Garriaon, G.A. 1972. Carbohydrate reserves and response to use. P. 271278 In: C.M. McKell, J.P. Blaisdell, and J.R. Goodin (eds), Wildland shrubs-their biology and utilization. USDA Forest Service Gen. Tech. Rep. Int-1, Ogden, Utah.

Guenther, W.C. 1964. Analysis of variance. Prentice Hall, Englewood Cliffs, N.J.

Hallisey, D.M., and G.W. Wood. 1976. Prescribed fire and scrub oak habitat in central Pennsylvania. J. Wildl. Manage. 40:507-516. 
Hardeaty, L.H. 1987. Factors affecting the sprouting response of woody caatinga species and their implications for improved caatinga management. Ph.D. diss., Utah State University, Logan.

Huss, D.L. 1976. Livestock production and range management in north east Brazil. Rangeman's J. 3:175-176.

Kirmae, R.D. 1984. Effects of clearcutting on forage production, quality, and decomposition in the caatinga woodland of northeast Brazil: implications to goat and sheep nutrition. Ph.D. diss., Utah State University, Logan.

Leege, T.A., and W.O. Hickey. 1971. Sprouting of northern Idaho shrub species after prescribed burning. J. Wildl. Manage. 35:508-515.

Lieberman, D., and M. Lieberman. 1984. The causes and consequences of synchronous flushing in a dry tropical forest. Biotropica 16:193-201.

PRister, J.A., and J.C. Malechek. 1986. Dietary selection by goats and sheep in a deciduous woodland of northeastem Brazil. J. Range Manage. 39:24-29.
Queiorz, J.S. 1985. The Acarau Valley in northeast Brazil: vegetation, soils, and land use. Ph.D. diss., Utah State University, Logan.

Ramon, A.D. 1981. Nocoes de pedologia, Empresa de Pesquisa Agropecuaria do Ceara'. Fortaleza, Brazil.

Reynolds, H.G., and A.W. Sampson. 1943. Chaparral crown sprouts as browse for deer. J. Wildl. Manage. 7:119-122.

Schaffalitzky de Muckadell, M. 1962. Environmental factors in development stages of trees. P. 289-297 In: T.T. Kozlowski (ed), Tree Growth. The Ronald Press Co., New York.

Statistical Analysis Systems. 1986. SAS Version 5. SAS Institute, Cary, N.C.

Zimmerman, M.H., and C.L. Brown. 1971. Trees, structure and function. Springer-Verlag, New York. 